\title{
Spirited Supreme Judge Contest
}

\author{
By EMORY H. ENGLish
}

The holding of state judicial conventions in Iowa has been a comparatively late development in state politics. Formerly the party candidates for supreme judges were nominated along with those for state officers in the party conventions. And not always could a judge succeed himself upon the Iowa supreme bench without surviving in hot political contests. One such took place in the Republican state convention held August 2, 1899, in Des Moines on occasion of Gov. L. M. Shaw's second nomination.

The term of Justice Gifford S. Robinson of Buena Vista county, was expiring the following January, and he was being opposed by a field of candidates consisting of four well known men who had served as district judges. They were Judge Geo. W. Burnham, of Vinton, Benton county, Judge John C. Sherwin, of Mason City, Cerro Gordo county, Thos. M. Fee, of Centerville, Appanoose county, and James D. Giffen, of Marion, Linn county.

Justice Robinson had a strong following and led on the first ballot, but eventually lost the contest, serving on the state supreme bench from 1888 to 1899 inclusive, and later as a member and chairman of the state board of control. Four ballots were necessary to make a nomination. Judge John C. Sherwin was second only to Judge Robinson on the first ballot. He gained on the second ballot, led the entire field on the third, and won on the fourth in an exciting finish of the contest.

Sherwin received aid from the Sloan and Fee forces, Judge Robinson pushing him hard through the added strength given by the support of a part of the Burnham forces, the rest going to Sherwin. The accession of the Sloan strength and some Burnham strength in 
the last roll call to the Sherwin camp was enough to land the nomination, however, for the Fourth district candidate, and Judge John C. Sherwin, for . eleven years judge of the Twelfth judicial district, was the nominee of the party for supreme judge.

Combination Sought By Burnham

Judge Burnham's defeat was predicted when the convention was called to order for the afternoon session. All week the Sherwin forces had resisted every attempt on the part of the Burnham leaders to force a combination looking to Burnham's nomination this year, in return for promises of Judge Sherwin's nomination one year later. Tuesday night the combination was all but effected. The Burnham managers were confident then that the morning would bring about the agreement and that success was assured their candidate. They said to the Sherwin people that the Updegraff strength in the east end of the Fourth congressional district stood ready to break from Sherwin because of the Blythe management of the campaign. It was predicted that this break would come early and that even if Sherwin should refuse to combine, his strength would be sapped away in the convention and that his forces would be badly demoralized by the time two or three ballots had been taken. The result showed the prediction a poor one.

On the other hand, the Sherwin men claimed that they could not afford to combine with a candidate who was having such trouble in his own congressional district as Judge Burnham was having in Linn county in contending with Giffen forces. Despite this claim, however, some of the Sherwin managers were ready to lay down on Tuesday evening. The threat of the Burnham followers to use the knife had had the effect of frightening the managers of Judge Sherwin's campaign, and they were almost ready to admit defeat and professed to the Burnham men that they were willing to combine with a view to ultimate success.

But their candidate himself had the nerve and con- 
fidence his managers seem to have lacked. He resisted every attempt of rival candidates to combine, unless he himself should be the winner. Even when his disheartened managers told him that defeat was practically certain if he insisted on standing alone, Sherwin declared that he believed that he was going to win and would continue to fight in that belief.

With the refusal of Sherwin to combine, the Burnham vote split, part going to Sherwin and part to Robinson, the larger part to the latter. Scott, Muscatine and Clinton counties, of the Second, helped out the Sherwin people, Polk county and the Seventh were about evenly divided. The Sloan' strength from the First district and part of the Fee strength in the Eighth district were delivered to Sherwin and nominated him, defeating Burnham. The principal break to Sherwin came with change of Van Buren county into the Sherwin column.

One of the gains to Sherwin from the Burnham column occurred in the third ballot. Muscatine county, of the Second district, had been looked upon as a strong Burnham county. But on the second ballot a change was made and the county threw the bulk of its vote to the Fourth district candidate. This was followed on the next ballot by Scott county. Scott had formerly been reckoned in the Burnham column. In the convention, however, it surprised everyone by dividing its vote, giving twenty votes to Burnham and seven to Giffen, his most bitter opponent, being in debt to both Linn county factions. On the third ballot it changed everything, however, and threw its entire twenty-seven votes to Judge Sherwin. The change from the time Van Buren threw over Sloan was rapid. Those counties interested, particularly in Mr. Gear, the Burlington senatorial candidate, hastened to climb into the band wagon, and the Sherwin gains were rapid.

That the candidacy of Judge Giffen was solely for the purpose of defeating Judge Burnham became 
more evident in the convention than ever before, although this had long been apparent. When on the fourth ballot, Benton withdrew Judge Burnham and announced its support of Judge Robinson, there were no more enthusiastic men on the floor than the managers of Judge Giffen. Linn county promptly changed from its course of opposing the rest of the district, and when it was called in the roll of counties, it swung into line and voted its thirty votes for Robinson, but too late to save him from defeat. The balloting upon the four roll calls had was as follows:

First ballot-Robinson 3161/2, Burnham 2381/2, Sherwin 262, Fee 2161/2, Sloan 1891/2 and Giffen 53 .

Second ballot-Robinson 3461/2, Burnham 1821/2, Sherwin 327, Fee 206, Sloan 168 and Giffen 32.

Third ballot-Robinson 3351/2, Burnham 1321/2, Sherwin 491 , Fee 176, Sloan 99 and Giffen 31.

Fourth ballot-Robinson $5097 / 10$, Burnham 11/2, Sherwin $6793 / 10$, Fee 90 .

Judge Sherwin was renominated and re-elected at the end of his term and served a total of twelve years on the Iowa supreme bench.

\section{Ruined Hands}

Parents who hear from their offspring the complaint: "I never can do a thing, never can have anything," may be sure it's nothing new, either in Iowa or elsewhere.

Sixteen-year-old Elizabeth Gurney Taylor wrote that phrase in her diary about 100 years ago.

Elizabeth was peeved on February 10, 1857, because she had to stay home and do household chores instead of attending a school program. She said she was ruining her hands by "washing dishes and cleaning spittoons."

Elizabeth lived on a farm near Three Rivers, Michigan. Her diary is part of the University of Michigan's historical collection. 
Copyright of Annals of Iowa is the property of State of Iowa, by \& through the State Historical Society of Iowa and its content may not be copied or emailed to multiple sites or posted to a listserv without the copyright holder's express written permission. However, users may print, download, or email articles for individual use. 